THURSDAY, JULY $7, \quad 1870$

PASTEUR'S RESEARCHES ON THE DISEASES OF SILIKWORMS

T HAVE recently received from $M$. Pasteur a copy of 1 his new work, "Sur la Maladie des vers à soie," a notice of which, however brief and incomplete, will, I am persuaded, interest a large class of the readers of NATURE. The book is the record of a very remarkable piece of scientific work, which has been attended with very remarkable practical results. For fifteen years a plague had raged among the silkworms of France. They had sickened and died in multitudes, while those that succeeded in spinning their cocoons furnished only a fraction of the normal quantity of silk. In 1853 the silk culture of France produced a revenue of one hundred and thirty millions of francs. During the twenty previous years the revenue had doubled itself, and no doubt was entertained as to its future augmentation. "Unhappily, at the moment when the plantations were most flourishing, the prosperity was annihilated by a terrible scourge." The weight of the cocoons produced in France in 1853 was twenty-six millions of kilogrammes; in 1865 it had fallen to four millions, the fall entailing in the single year last mentioned a loss of one hundred millions of francs.

The country chiefly smitten by this calamity happened to be that of the celebrated chemist Dumas, now perpetual secretary of the French Academy of Sciences. He turned to his friend, colleague, and pupil, Pasteur, and besought him with an earnestness which the circumstances rendered almost personal, to undertake the investigation of the malady. Pasteur at this time had never seen a silkworm, and he urged his inexperience in reply to his friend. But Dumas knew too well the qualities needed for such an inquiry to accept Pasteur's reason for declining it. "Je met," said he, "un prix extrème à voir votre attention fixée sur la question qui interesse mon pauvre pays ; la misère surpasse tout ce que vous pouvez imaginer." Pamphlets about the plague had been showered upon the public, the monotony of waste paper being broken at rare intervals by a more or less useful publication. "The Pharmacopœia of the Silkworm," wrote M. Cornalia in 1860 , "is now as complicated as that of man. Gases, liquids, and solids have been laid under contribution. From chlorine to sulphurous acid, from nitric acid to rum, from sugar to sulphate of quinine,--all has been invoked in behalf of this unhappy insect." The helpless cultivators, moreover, welcomed with ready trustfulness every new remedy, if only pressed upon them with sufficient hardihood. It seemed impossible to diminish their blind confidence in their blind guides. In 1863 the French Minister of Agriculture himself signed an agreement to pay 500,000 francs for the use of a remedy which its promoter declared to be infallible. It was tried in twelve different departments of France and found perfectly useless. In no single instance was it successful. It was under these circumstances that M. Pasteur, yielding to the entreaties of his friend, betook himself to Alais in the beginning of June 1865. As regards silk husbandry, this was the most important department. in France, and it was also that which had been most sorely smitten by the epidemic.
The silkworm had been previously attacked by muscardine; a disease proved by Bassi to be caused by a vegetable parasite. Muscardine, though not hereditary, was propagated annually by the parasitic spores, which, wafted by winds, often sowed the disease in places far removed from the centre of infection. According to Pasteur, muscardine is now very rare; but for the last fifteen or twenty years a deadlier malady has taken its place. A frequent outward sign of this disease are the black spots which cover the silkworms, hence the name pébrine, first applied to the plague by $M$. de Quatrefages, and adopted by Pasteur. Pébrine also declares itself in the stunted and unequal growth of the worms, in the languor of their movements, in their fastidiousness as regards food, and in their premature death. The discovery of the inner workings of the epidemic may be thus traced. In 1849 Guerin Méneville noticed in the blood of certain silkworms vibratory corpuscles which he supposed to be endowed with independent life, and to which he gave a distinctive name. As regards the motion of the particles, Filippi proved him wrong; their motion was the well-known Brownian motion. But Filippi himself committed the error of supposing the corpuscles to be normal to the life of the insect. They are really the cause of its mortality - the form and substance of its disease. This was stualied and well clescribed by Cornalia ; while Lebert and Frey subsequently found the corpuscles not only in the blood, but in all the tissues of the silkworm. Osimo, in 1857 , discovered the corpuscles in the eggs, and on this observation Vittadiani founded, in 1859 , a practical method of distinguishing healthy from diseased eggs. The test often proved fallacious, and it was never extensively applied.

The number of these corpuscles is sometimes enormous. They take possession of the intestinal canal, and spread thence throughout the body of the worm. They fill the silk cavities, the stricken insect often going through the motions of spinning without any material to answer to the act. Its organs, instead of being filled with the clear viscous liquid of the silk, are packed to distension by these corpuscles. On this feature of the plague Pasteur fixed his attention. He pursued it with the skill which appertains to his genius, and with the thoroughness that belongs to his character. The cycle of the silkworm's life is briefly this:- From the fertile egg comes the little worm, which grows, and after some time casts its skin. This process of moulting is repeated two or three times at subsequent intervals during the life of the insect. After the last moulting the worm climbs the brambles placed to receive it, and spins among them its cocoon. It passes thus into a chrysalis; the chrysalis becomes a moth, and the moth when liberated lays the eggs which form the starting-point of a new cycle. Now Pasteur proved that the plague-corpuscles might be incipient in the egg, and escape detection ; they might also be germinal in the worm, and still baffle the microscope. But as the worm grows, the corpuscles grow also, becoming larger and more defined. In the aged chrysalis they are more pronounced than in the worm; while in the moth, if either the egg or the worm from which it comes should have been at all stricken, the corpuscles infallibly appear, offering no difficulty of detection. This was the first great point made out in $\mathbf{I} 865$ by Pasteur. The Italian naturalists, as aforesaid, recommended the examination of the eggs 
before risking their incubation. Pasteur showed that both egss and worms might be smitten and still pass muster, the culture of such egys or such worms being sure to entail disaster. He made the moth his starting-point in seeking to regenerate the race.

And here is to be noted a point of immense practical importance. The worms issuing from tha eggs of perfectly healthy moths may afterwards become themselves infected through contact with diseased worms, or through germs mixed with the dust of the rooms in which the worms are fed. But though the moths derived from the worms this infected may be so charged with corpuscles as to be totally unable to produce eggs fit for incubation, still Pasteur shows that the worms themselves, in which the disease is not hereditary, never perish before spinning their cocoons. This, as I have said, is a point of capital importance; because it shows that the mothtest, if acted upon, even though the worms during their "education" should contract infection, secures, at all events, the next subsequent crop.

Pasteur made his first communication on this subject to the Academy of Sciences in September r 865. It raised a cloud of criticism. Here forsooth was a chemist rashly quitting his proper métier and presuming to lay down the law for the physician and biologist on a subject which was eminently theirs. "On trouva étrange que je fusse si peu au courant de la question; on m' opposa des travaux qui avaient paru depuis longtemps en Italie, dont les resultats montraient l'inutilité de mes efforts, et l'impossibilité d'arriver à un resultat pratique dans la direction que je m'étais engagé. Que mon ignorance fut grande au sujet des recherches sans nombre qui avaient paru depuis quinze années." Pasteur heard the buzz, but he continued his work. In choosing the eggs intended for incubation, the cultivators selected those produced in the successful "educations" of the year. But they could not understand the frequent and often disastrous failures of their selected eggs; for they did not know, and nobody prior to Pasteur was competent to tell them, that the finest cocoons may envelop doomed corpusculous moths. It was not, however, easy to make the cultivators accept new guidance. To strike their imagination and if possible determine their practice, Pasteur hit upon the expedient of prophecy. In I 865 he inspected at St. Hippolyte-duFort fourteen different parcels of eggs intended for incubation. Having examined a sufficient number of the moths which produced these eggs, he wrote out the prediction of what would occur in 1867 , and placed the prophecy as a sealed letter in the hands of the Mayor of St. Hippolyte.

In 1867 the cultivators communicated to the mayor their results. The letter of Pasteur was then opened and read, and it was found that in twelve out of fourteen cases, there was absolute conformity between his prediction and the observed facts. Many of the educations had perished totally; the others had perished almost totally; and this was the prediction of Pasteur. In two out of the fourteen cases, instead of the prophesied destruction, half an average crop was obtained. Now, the parcels of eggs here referred to were considered healthy by their owners. They had been hatched and tended in the firm hope that the labour expended on them would prove remunerative. The application of the moth-test for a few minutes in 1866 would have saved the labour and averted the disappointment. Two additional parcels of eggs were at the same time submitted to Pasteur. He pronounced them healthy; and his words were verified by the production of an excellent crop. Other cases of prophecy still more remarkable, because more circumstantial, are recorded in the work before us.

These deadly corpuscles were found by Leydig in other insects than the silkworm moth. He considers them to belong to the class of psososperms founded by $\mathrm{J}$. Müller. "This," says Pasteur, "is to regard the corpuscular organism as a kind of parasite, which propagates itself after the manner of parasites of its class." Pasteur subjected the development of the corpuscles to a searching examination. With admirable skill and completeness he also examined the various modes by which the plague is propagated. He obtained perfectly healthy worms from moths perfectly free from corpuscles, and selecting from them $10,20,30,50$, as the case might be, he introduced into the worms the corpusculous matter. It was first permitted to accompany the food. Let us take a single example out of many. Rubbing up a small corpusculous worm in water, he smeared the mixture over the mulberry leaves. Assuring himself that the leaves had been eaten, he watched the consequences from day to day. Side by side with the infected worms he reared their fellows, keeping them as much as possible out of the way of infection. These constituted his "lot temoign," his standard of comparison. On the I6th of April, I868, he thus infected thirty worms. Up to the $23 \mathrm{rd}$ they remained quite well. On the $25^{\text {th }}$ they seemed well, but on that day corpuscles were found in the intestines of two of the worms subjected to microscopic examination. The corpuscles begin to be formed in the tunic of the intestine. On the 27 th, or eleven days after the infected repast, two fresh worms were examined, and not only was the intestinal canal found in each case invaded, but the silk organ itself was found charged with the corpuscles. On the 28 th the twenty-six remaining worms were covered by the black spots of pébrine. On the 3 oth the difference of size between the infected and non-infected worms was very striking, the sick worms being not more than two-thirds of the size of the healthy ones. On the 2 nd of May a worm which had just finished its fourth moulting was examined. Its whole body was so filled with corpuscles as to excite astonishment that it could live. The disease advanced, the worms died and were examined, and on the IIth of May only six out of the thirty remained. They were the strongest of the lot, but on being searched they also were found charged with corpuscles. Not one of the thirty worms had escaped; a single corpusculous meal had poisoned them all. The standard lot, on the contrary, spun their fine cocoons, and two only of their moths were found to contain any trace of corpuscles. These had doubtless been introduced during the rearing of the worms.

As his acquaintance with the subject increased, Pasteur's desire for precision augmented, and he finally gives the growing number of corpuscles seen in the field of his microscope from day to day. After a contagious repast the number of worms containing the parasite gradually augmented until finally it became cent. per cent. The number of corpuscles would at the same time rise from $O$ to $I$, to $I 0$, to 100 , and sometimes even 
to 1,000 or 1,500 for a single field of his microscope. He then varied the mode of infection. He inoculated healthy worms with the corpusculous matter, and watched the consequent growth of the disease. He showed how the worms inoculate each other by the infliction of visible wounds with their "crochets." In various cases he washed the "crochets," and found corpuscles in the water. He demonstrated the spread of infection by the simple association of healthy and diseased worms. In fact, the diseased worms sullied the leaves by their dejections, they also used their crochets, and spread infection in both ways. It was no hypothetical infected medium that killed the worms, but a definitely-organised and isolated thing. $\mathrm{He}$ examined the question of contagion at a distance, and demonstrated its existence. In fact, as might be expected from Pasteur's antecedents, the investigation was exhaustive, the skill and beauty of his manipulation finding fitting correlatives in the strength and clearness of his thought.

Pébrine was an enigma prior to the experiments of Pasteur. "Place," he says, "the most skilful educator, even the most expert microscopist, in presence of large educations which present the symptoms described in our experiments ; his judgment will necessarily be erroneous if he confines himself to the knowledge which preceded my researches. The worms will not present to him the slightest spot of pébrine; the microscope will not reveal the existence of corpuscles; the mortality of the worms will be null or insignificant; and the cocoons leave nothing to be desired. Our observer would, therefore, conclude without hesitation that the eggs produced will be good for incubation. The truth is, on the contrary, that all the worms of these fine crops have been poisoned; that from the beginning they carried in them the germ of the malady; ready to multiply itself beyond measure in the chrysalides and the moths, thence to pass into the eggs and smite with sterility the next generation. And what is the first cause of the evil concealed under so deceitful an exterior? In our experiments we can, so to speak, touch it with our fingers. It is entirely the effect of a single corpusculous repast; an effect more or less prompt according to the epoch of life of the worm that has eaten the poisoned food."

It was work like this that I had in view when, in a lecture which has brought me much well-meant chastisement from a certain class of medical men, and much gratifying encouragement from a different chacs, I dwelt on the necessity of experiments of physical exactitude in testing medical theories. It is work like this which might be offered as a model to the physicians of England, many indeed of whom are pursuing with characteristic skill and energy the course marked out for them by this distinguished master. Prior to Pasteur, the most diverse and contradictory opinions were entertained as to the contagious character of pébrine; some stoutly affirmed it, others as stoutly denied it. But on one point all were agreed. "They believed in the existence of a deleterious medium, rendered epidemic by some occult and mysterious influence, to which was attributed the cause of the malady." Between such notions and the work of Pasteur, no physically-minded man will, I apprehend, hesitate in his choice.

Pasteur describes in detail his method of securing healthy eggs, which is nothing less than a mode of restor- ing to France her ancient prosperity in silk husbandry. And the justification of his work is to be found in the reports which reached him of the application, and the unparalleled success of his method, at the time he was putting his researches together for final publication. In France and Italy his method has been pursued with the most surprising results. It was an up-hill fight which led to this triumph, but it is consoling to think that even the stupidities of men may be converted into elements of growth and progress. Opposition stimulated Pasteur, and thus, without meaning it, did good service. "Ever," he says, "since the commencement of these researches, I have been exposed to the most obstinate and unjust contradictions; but $I$ have made it a duty to leave no trace of these contests in this book." I have met witl only a single allusion to the question of spontaneous generation in M. Pasteur's work. In reference to the advantage of rearing worms in an isolated island like Corsica, he says:-_"Rien ne serait plus facile que d'éloigner, pour ainsi dire, d'une manière absolue la maladie des corpuscles. Il est au pouvoir de l'homme de faire disparaître de la surface du globe les maladies parasitaires, si, comme c'est ma conviction, la doctrine des générations spontanées est une chimère." It is much to be desired that some really com. petent person in England should rescue the public mind from the confusion now prevalent regarding this question.

M. Pasteur has investigated a second disease, called in France flacherie, which has co-existed with pébrine, but which is quite distinct from it. Enough, I trust, has been said to send the reader interested in these questions to the original volumes for further information. I report with deep regret the serious illness of M. Pasteur; an illness brought on by the labours of which I have tried to give some account. The letter which accompanied his volumes ends thus:- "Permettez-moi de terminer ces quelques lignes que je dois dicter, vaincu que je suis par ia maladie, en vous faisant observer que vous rendiez service aux Colonies de la Grande Bretagne en repandant la connaissance de ce livre, et des principes que j'établis touchant la maladie des vers à soie. Beaucoup de ces colonies pourraient cultiver le mûrier avec succès, et en jetant les yeux sur mon ouvrage vous vous convaincrez aisement qu'il est facile aujourdhui, non seulement d'éloigner la maladie régnante, mais en outre de donner aux récoltes de la soie une prospérité qu'elles n'ont jamais eue.'

Royal Institution, zoth June

JOHN TYNDALL

\section{WHAT IS ENERGY?}

\section{III.}

\section{THE CONSERYATION OF ENERGY}

$T^{T}$ is well-known that certain organisms of the animal world do not confine themselves to one state of being or to one order of existence, and the most familiar instance of this roving habit of life is the caterpillar, which passes first into the chrysalis state, and after that into the butterfly. This habit is not, however, peculiar to the organic world, for energy delights in similar transmutations, and we have just seen how the eminently silent and invisible electrical current may occasionally be transmuted into the vivid, instantaneous, awe-inspiring flash of lightning. Nor is this element of change confined to our peculiar corner of the universe, but it extends itself to 